\title{
The Intersection of Place and Ethnic Entrepreneurship: The Role of Ethnic Entrepreneurs in the Making of Three Toronto Neighbourhoods
}

\section{Zhixi Cecilia Zhuang}

Ryerson University

Please Cite:

Zhuang, Z. C. (2017). The intersection of place and ethnic entrepreneurship: The role of ethnic entrepreneurs in the making of three Toronto neighbourhoods. Journal of Architectural and Planning Research. 34(1): 1-22.

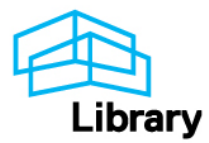


The Intersection of Place and Ethnic Entrepreneurship: The Role of Ethnic Entrepreneurs in the Making of Three Toronto Neighbourhoods

\author{
Dr. Zhixi Cecilia Zhuang \\ Associate Professor \\ School of Urban and Regional Planning \\ Ryerson University, Toronto, Canada \\ zczhuang@ryerson.ca
}

To cite this article: Zhuang, Z. C. 2017. The Intersection of Place and Ethnic Entrepreneurship: The Role of Ethnic Entrepreneurs in the Making of Three Toronto Neighbourhoods. Journal of Architectural and Planning Research. 34(1): 1-22.

\begin{abstract}
:
Ethnic retail neighbourhoods in the Toronto area are not only indicators of Canada's ethnocultural diversity, but also important social places where ethnic businesses have made longlasting physical impressions on urban landscapes. This paper aims to investigate the social, economic, and physical processes of the making of ethnic retail places and the role of ethnic entrepreneurs in these processes. It explores three ethnic retail strips in Toronto's inner city targeting the Chinese, South Asian, and Italian business communities. Key informant interviews, shopper intercept surveys, and field observations were conducted. The findings reveal profound inter-group differences, and demonstrate that ethnic entrepreneurs are the driving force behind the social, economic, and physical processes of neighbourhood transformation. These findings will help bridge research gaps associated with the spatial and physical aspects of ethnic entrepreneurship and offer empirical knowledge for municipalities.
\end{abstract}




\section{Autobiographical Sketch:}

Dr. Zhixi Cecilia Zhuang is an Associate Professor in the School of Urban and Regional Planning at Ryerson University. Her current research focuses on emerging suburban ethnic retail landscapes and aims to explore place-making practices in these ethnic retail neighbourhoods and implications for municipal planning.

\section{Acknowledgment:}

This article was completed with financial support from the Faculty of Community Services, Ryerson University. I would like to acknowledge the help of the participants in this study who generously contributed their time and shared their perspectives with me. They made this research possible. Special thanks go to my colleagues, Dr. Pamela Robinson, Dr. Christopher De Sousa, and the anonymous reviewers for their insightful comments. The author is, of course, solely responsible for the content of this article. 


\section{The Intersection of Place and Ethnic Entrepreneurship: The Role of Ethnic Entrepreneurs in the Making of Three Toronto Neighbourhoods}

\section{Introduction}

Canada has long been a country of immigrants. According to the 2011 National Household Survey, one-fifth (20.6\%) of Canada's total population was foreign-born, and more than 200 different countries of origin were reported. Visible minorities ${ }^{1}$ accounted for $19.1 \%$ of the total population. Geographically, nearly two-thirds of all foreign-born immigrants in Canada (63.4\%) lived in just three 'gateway cities' - Toronto (37.4\%), Vancouver (13.5\%), and Montréal (12.5\%) (Statistics Canada, 2013).

Various waves of immigration have changed urban landscapes in ways that reflect Canada's ethno-cultural diversity. One of the most noticeable changes is ethnic retail neighbourhoods, which consist of concentrated co-ethnic businesses and have well-recognized names, such as Chinatown, Little Italy, and Little India (Bauder and Suorineni, 2010; Lai, 1988; Wang, 1999). Although local retail development is typically in the domain of local economic development offices, planners should better understand the ethnic retail phenomenon because of the significant social, economic, and environmental benefits it generates. First, ethnic retailing contributes to the integration of immigrants, both socially and culturally. Ethnic retail areas serve as 'little homelands' or social hubs for immigrants who have strong cultural attachments to these areas (Buzzelli, 2001; Teixeira, 2006). For the community at large, ethnic retail areas showcase diverse ethno-cultural heritages and are often treated as symbols of Canada's multiculturalism; 
they also contribute to the identity of the adjacent neighbourhood (Hackworth and Rekers, 2005; Kumar and Martin, 2004). Second, the presence of ethnic retail districts not only promotes the creation of small businesses and hence employment, but also diversifies the urban retail environment by providing local, diverse, and easily accessible shopping options (Jones, 2000). Third, ethnic retailing has the potential to stabilize, revitalize, and sustain existing neighbourhoods. Empirical studies have shown that as ethnic businesses concentrate and succeed in once-declining neighbourhoods, they usually play a role in revitalizing local economy and neighbourhood space by attracting customers and investments to the area (Kaplan and Li, 2006; Kloosterman and Van der Leun, 1999; Loukaitou-Sideris, 2002; Rath, 2007). These effects are clearly within the planners' domain and worthy of further study.

Despite a growing body of literature about ethnic entrepreneurship, few scholars planners, geographers, or otherwise - have focused on the spatial and physical dimensions of the ethnic retail phenomenon. Relatively little is known about how ethnic retail space is produced and consumed, or about its spatial (e.g., locations and relations to existing neighbourhoods) and physical (e.g., forms and functions) effects on existing neighbourhoods. It is also unclear how ethnic entrepreneurs are involved in creating an ethnic retail 'place' (as opposed to 'space') with its own identity. Within the literature, debates about space and place are complex, and although they often take place within the context of geography, they provide useful conceptualizations. For example, also within the field of geography, Agnew (1987) specified three required dimensions that turn 'space' into 'place:' a specific location, a locale associated with everyday activities, and a sense of place. Tuan (1974) emphasized human attachment and lived experience that identifies a place with its own identity, and makes abstract space become place. 
Within city planning, theoretical discussions originated decades ago, when visionary urbanists such as Jacobs (1961), Lynch (1960), and Whyte (1980) advocated for adopting a people-oriented approach to create lively and meaningful urban places. Today, 'place-making' is considered "both a process and a philosophy" in planning practice (PPS, 2014: para. 6). Silberberg et al. (2013) argued that the process of making a place is as important as the place itself, and that the process should be people-driven to ensure long-lasting benefits for community.

The purpose of the research presented here is not to debate about space and place, but to explore the making of a place within the context of ethnic retailing and ethnic entrepreneurship. Here, 'place' can be understood as "the geographical context for the mediation of physical, social and economic processes" (Agnew, 2011: 317). A 'retail place,' therefore, can be defined as a physical business environment that accommodates and facilitates social interactions and economic activities. As noted, many ethnic retail areas serve as community and economic hubs by combining retail, dining, entertainment, and personal services; they also contribute to the retrofitting of existing neighbourhoods. As places with greater importance than simply locations to shop, more research is required to clarify the role of ethnic entrepreneurs in the making of ethnic retail neighbourhoods.

The research presented in this article sought to address this gap through a study of three ethnical retail neighbourhoods in one of the world's most diverse cities: Toronto, Canada. The paper reports on findings related to the primary question: How have ethnic entrepreneurs contributed to the making of three ethnic retail places in Toronto, namely East Chinatown, Gerrard India Bazaar, and Corso Italia? To address this primary research question, this paper 
aims to clarify how these ethnic retail sites have developed over time and how their current form and function have been shaped by ethnic entrepreneurs in each area. Doing so required an examination of the relationships between businesses in the area, the client base, the surrounding residential neighbourhoods, and municipal decision makers (i.e., politicians, city planners, and economic development officers). Different attributes represented in the studied neighbourhoods were observed and analyzed, including the retail forms, locations, ethnicities (e.g., comparison of different groups), business profiles, development histories and patterns, and business organizations. Qualitative data were collected through 52 interviews with key informants including merchants, city officials, and community agency representatives, and through 28 'shopper intercept surveys. ${ }^{2}$ The findings helped clarify the formation of diverse ethnic retail places, and revealed profound inter-group differences and the important role that ethnic entrepreneurs play in the making of these retail places. This paper concludes with several implications for municipalities regarding facilitating and enhancing ethnic retail places.

\section{Research Context: The Intersection of Place and Ethnic Entrepreneurship}

Extensive research has revealed many dimensions of ethnic entrepreneurial behaviours and performances in different ethnic groups and metropolitan areas. ${ }^{3}$ However, few researchers have explored the spatial and physical outcomes of these entrepreneurial processes. In a comprehensive review of interdisciplinary literature on ethnic entrepreneurship from a spatial perspective, Wang concluded, "even less is known about how space, place, and race/ethnicity interact in the process of entrepreneurship" (2013: 98). Wang went on to argue that place is "both a container and mechanism through which the strategic space and opportunities are created and 
adapted by ethnic entrepreneurs" (2013: 100). Place plays an important role in shaping ethnic entrepreneurial experiences and reflects the interactions between ethnic entrepreneurs and their physical and business environments.

Place is most often discussed in studies of ethnic enclave economies. ${ }^{4}$ However, these studies have tended to focus on the economic outcomes of ethnic entrepreneurship, rather than the spatial and physical dimensions. Adding a spatial dimension to discussions about ethnic entrepreneurship, Kaplan (1998) conceptualized four general ways in which spatial concentration can have a positive effect on ethnic businesses: incubator, linkage, agglomeration, and focus effects. Based on her research on the Chinese community in Los Angeles, Li (1998a, 1998b, 2009) proposed a new model of ethnic settlement, the 'ethnoburb,' wherein suburban clusters of residential and business areas integrate the ethnic economy with the local mainstream economy and are transformed into global economic outposts. These studies help clarify the spatial distribution of ethnic businesses at a macro metropolitan level; yet at a micro neighbourhood level, more empirical research is needed to clarify how ethnic retail activities help shape the physical business environment, and in turn, how the physical characteristics and qualities of a place affect the operations of ethnic businesses. The present paper addresses this need.

As a response to the rapid growth of ethnic communities and their imprints upon urban landscapes, a number of studies have explored the commercial activities and identities associated with ethnic places (Collins, 2006; Kaplan and Li, 2006; Lin, 2011; Loukaitou-Sideris, 2002; Teixeira, 2006; Wood, 1997). In their edited book, Kaplan and Li addressed the role of spatial capital (rather than financial capital, human capital, or ethnic or social capital) in ethnic economies. They used a series of case studies to illustrate "how spatial concentration (at 
whatever scale) can operate as a resource" (2006: 7) to benefit the development of ethnic economies, and in turn, how "ethnic businesses make and mark ethnic places" (2006: 10). Typical examples, such as the residentially segregated business enclave of Little Portugal in downtown Toronto and the suburban business precincts of Little Italy and Asiatown in Sydney, reveal the making of retail places at different geographical scales and among various ethnic groups (Collins, 2006; Teixeira, 2006). Kaplan and Li (2006) concluded that making ethnic business concentration an effective resource depends on group characteristics, metropolitan spatial context (e.g., compact vs. sprawling urban form), the development stage of the ethnic economy, and the types of businesses involved. Therefore, ethnic retail landscapes not only reflect how ethnic entrepreneurs operate their businesses spatially and physically, but also how these retail places affect the quality of the existing urban space, which has wider effects on the neighbourhood as a whole. While these results help clarify the spatial and physical aspects of the ethnic retail neighbourhoods, ethnic entrepreneurs - the major actors in the making of these places - deserve more attention.

According to Rath (2007), ethnic entrepreneurs can influence the spatial and physical manifestations of retail areas because they are embedded in the wider economic, political, and institutional structures. Based on data from more than 3000 counties in the United States from 1970-2010, Vigdor concluded that immigrants "are a key part of the American success story at the community level, revitalizing local areas and creating economic growth and jobs for U.S.born workers" (2013: 2). In many cases, ethnic entrepreneurs contribute to urban revitalization by restoring social, cultural, and economic vitality to declining urban areas (Buzzelli, 2001; Loukaitou-Sideris, 2002; Teixeira, 2006; Wood, 1997; Zhou, 1998). Neighbourhood 
revitalization associated with immigrant entrepreneurs and ethnic branding leading to higher real estate value and significant community transformations has been documented in various countries, including Canada, the United States, and the Netherlands (Hackworth and Rekers, 2005; Kloosterman and Van der Leun, 1999; Loukaitou-Sideris, 2002). The New York Times reported that some American cities like Dayton, Ohio, and Utica, New York have demonstrated promising practices in attracting refugees and immigrants to settle and open businesses in order to revitalize once-declining industrial towns (Hartman, 2014; Preston, 2013). However, municipal strategies for downtown and retail revitalization tend to overlook the potential role of ethnic businesses and communities as an untapped resource for revitalizing declining urban areas (Robertson, 1997, 2002). Municipalities will benefit from more empirical research on the impact of ethnic businesses on urban revitalization.

According to Wang, “The interaction between the entrepreneur and their environments is not static, but varies across time and space, contingent on the historical political system, cultural legacy, and discriminatory practices in the labor markets" (2012: 233). Many ethnic retail neighbourhoods, such as those in the Toronto area, have undergone ethnic successions and different stages of development. This study focused on the development of three such retail neighbourhoods in Toronto's inner city: East Chinatown, the Gerrard India Bazaar, and Corso Italia, and how these places were produced, modified, readapted, and transformed by ethnic entrepreneurs (Figure 1). These business communities were selected because they represent the influences of different immigration policies and histories and provided a variety of samples for an exploratory study and for comparisons between and within groups. ${ }^{5}$ 


\section{Figure 1. Locations of the Three Case Studies}

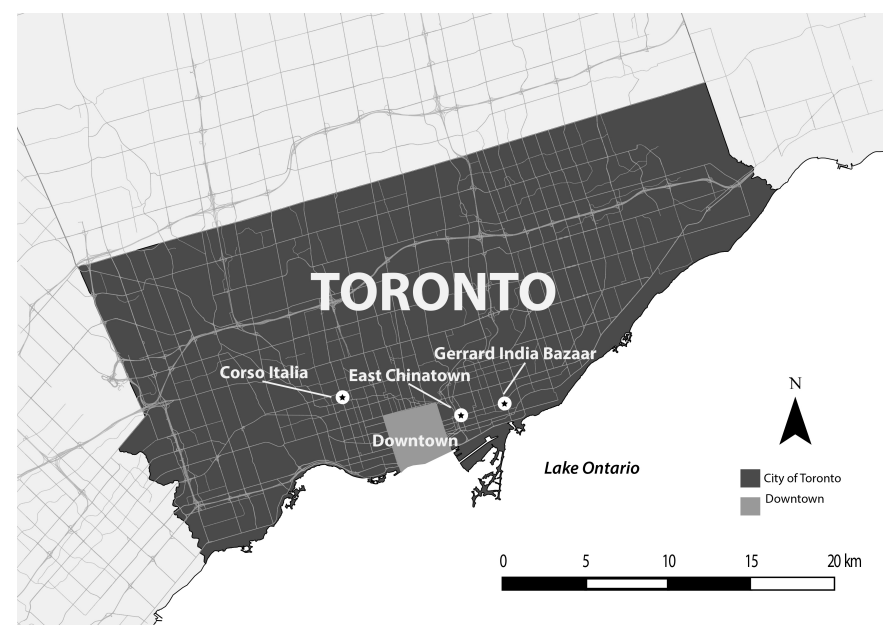

\section{Research Approach}

As per the definition of 'place' noted earlier, this research framed the ethnic retail phenomenon as a social, economic, and physical construct and investigated how ethnic entrepreneurs play a role in the development of the three retail neighbourhoods. In order to understand the development of these places, the study used multiple data collection methods including analysis of secondary documents about the studied areas, archival records of demographics and businesses, site observations of social interactions, business activities, physical features, and qualitative interviews (described below).

Two sets of quantitative data were analyzed to characterize the population and business profiles for each case. The first was the annual business survey conducted between 2000 and 2009, retrieved from the Centre for the Study of Commercial Activity (CSCA) at Ryerson University. Its major indicators include business composition and vacancy rate. The second was a series of neighbourhood census profiles based on the 2006 Canadian Census and compiled by the 
City of Toronto. The three inner-city strips of East Chinatown, Gerrard India Bazaar, and Corso Italia are located in the neighbourhoods of South Riverdale, Greenwood-Coxwell, and Corso Italia-Davenport, respectively. At the time of the study, each neighbourhood included at least two census tracts, and had a minimum neighbourhood population between 7,000 and 10,000.

Thirteen information interviews were conducted with key informants (e.g., business leaders, local librarians, academics) who are knowledgeable about the study areas (Table 1). They were asked about neighborhood development histories and related issues. These interviews helped inform the next phase of the interviews and the selection of second round of key informants. Thirty-nine semi-structured interviews were later conducted with ethnic entrepreneurs, community agency staff, and city officials (councilors, planners, and economic development officers) (Table 1). All semi-structured interviews were audio-taped and transcribed using verbatim transcriptions. Interviews that were conducted in Chinese were later translated and transcribed into English. The mass of qualitative data was condensed by clustering it into manageable categories, and then using expressive meanings to address the research questions and clarify emerging results. This iterative process involved interpreting the data, identifying themes, developing codes, making intra-case and cross-case comparisons and contrasts, displaying information in matrixes, and cross-checking or verifying emerging themes (see Marshall and Rossman 2011; Yin 2003). This semi-structured interview data set provides a wide spectrum of perspectives on the development processes in the three ethnic retail neighbourhoods and the roles of ethnic entrepreneurs in these processes. In addition, 28 shoppers were intercepted on the shopping strips.

Table 1: Summary of Research Participants 


\begin{tabular}{|c|c|c|c|c|c|}
\hline & & EC & GIB & CI & Total \\
\hline \multirow{5}{*}{$\begin{array}{l}\text { Semi- } \\
\text { structured } \\
\text { interviews }\end{array}$} & Merchants & 7 & 7 & 8 & \multirow[t]{5}{*}{39} \\
\hline & $\begin{array}{l}\text { City Councilors and } \\
\text { Assistants }\end{array}$ & \multicolumn{2}{|c|}{3} & 3 & \\
\hline & Planners & \multicolumn{2}{|c|}{1} & 3 & \\
\hline & $\begin{array}{l}\text { Economic } \\
\text { Development Officers }\end{array}$ & 1 & 1 & 1 & \\
\hline & $\begin{array}{l}\text { Community Agency } \\
\text { Staff }\end{array}$ & \multicolumn{2}{|c|}{3} & 1 & \\
\hline \multirow{6}{*}{$\begin{array}{l}\text { Information } \\
\text { Interviews }\end{array}$} & Business Leaders & 2 & 1 & 1 & 13 \\
\hline & Local Librarians & 1 & 1 & 1 & \\
\hline & $\begin{array}{l}\text { Community Agency } \\
\text { Staff }\end{array}$ & \multicolumn{2}{|c|}{1} & $\mathrm{~N} / \mathrm{A}$ & \\
\hline & \multirow[t]{2}{*}{ Academics } & $\mathrm{N} / \mathrm{A}$ & 1 & 1 & \\
\hline & & \multicolumn{3}{|c|}{2 specializing in general urban retail } & \\
\hline & Planners & \multicolumn{3}{|c|}{1} & \\
\hline $\begin{array}{l}\text { Intercept } \\
\text { Survey }\end{array}$ & Consumers & 8 & 10 & 10 & 28 \\
\hline & & & & & 80 \\
\hline
\end{tabular}

* $\mathrm{EC}=$ East Chinatown; GIB $=$ Gerrard India Bazaar; $\mathrm{CI}=$ Corso Italia

Interviews with ethnic entrepreneurs focused on their business profiles, location preferences, spatial needs, development issues, and experiences with city officials. Interviewees in each strip were selected to reflect ethno-racial diversity. Other interviews focused on neighbourhood development processes and issues, municipal involvement, and experiences with the business community. The shopper intercept survey mainly focused on the purpose of the shopping trip, the shopper's ethnic origins, distance from home, shopping frequency, what the place meant to the shopper and why, and what the shopper liked most about the particular retail area compared with others. 
In the next sections, the paper will discuss the social, economic, and physical processes in the development of the three cases. Social processes refer to the composition of local residents, merchants, and shoppers, their uses of the retail strip, and possible social interactions among these users. Economic processes refer to business composition and organization, and related commercial activities. Physical processes include physical improvements, transformations, and developments.

\section{East Chinatown: A Traditional Ethnic Enclave Under Revitalization}

East Chinatown centres on the intersection of Gerrard Street East and Broadview Avenue in the east end of the inner city of Toronto. It was established in the 1960s, a decade of so-called urban renewal, when the original Chinatown was demolished to make way for a new city hall and a new Downtown Chinatown at Dundas Street West and Spadina Avenue boosted property values. At this time, many Chinese businesspersons chose the east end because it offered lower real estate and rental prices, good public facilities (e.g., parks and a library), and convenient public transit connections to downtown (Lai, 1988; Wang, 1996). East Chinatown started to boom in the 1980s (Figure 2).

Figure 2: East Chinatown Streetscape

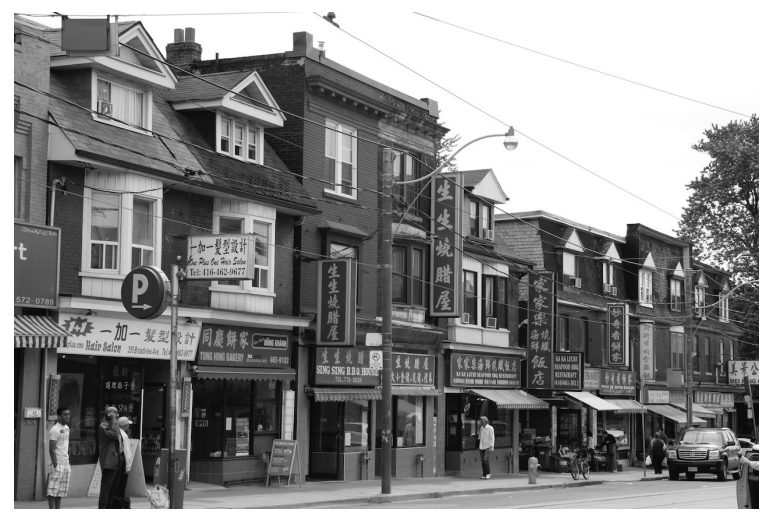




\section{Social Processes}

Despite the ubiquity of Chinatowns in large North American cities, not all Chinatowns are the same nor are they static ethnic enclaves. East Chinatown and the adjacent neighbourhood is dominated by the Chinese population: according to the 2006 Canadian Census, $23.1 \%$ of the neighbourhood population spoke Chinese at home, nearly three times the average in the City of Toronto (8.3\%). The neighbourhood's Chinese population by ethnic origin $(33.1 \%)$ and by visible minority group (31.6\%) were also much higher than the city average $(12.5 \%$ and $11.4 \%$, respectively) (City of Toronto 2008a). Qadeer et al. classified this type of ethnic concentration as a secondary concentration: "a census tract in which persons of a particular ethnic background are the single largest group, though not a majority (i.e. between $25 \%$ and $49 \%$ )" (2010: 325$)$. They found that certain ethnic groups (i.e., Chinese, South Asian, Italian, Jewish, Portuguese) have mainly secondary concentrations in the inner city of Toronto, with larger concentrations in the suburbs.

However, the Census data do not differentiate among Chinese sub-ethnicities. The Chinese community is, in fact, very heterogeneous, with numerous subgroups that have regional, dialectical, and cultural differences. This diversity is not surprising given China's population of over 1.35 billion, with numerous dialects spoken under seven language families, and 55 ethnic subminority groups. The origins of the Chinese business owners in East Chinatown reflect this diversity as reported by the interviewed entrepreneurs. However, according to one interviewed Chinese business leader, “City officials don’t have a clear idea on what exactly Chinese culture is," let alone the intra-group diversity. The same business leader also emphasized that to make 
city officials more aware of cultural diversity, the Chinese business community "must express ourselves and make our voice heard. Otherwise, they can't really understand."

Most of the early businesses in East Chinatown were owned by Hong Kong immigrants and other Cantonese immigrants. In the 1980s, Hong Kong entrepreneurs retreated from the area and moved to the suburban fringes of the Toronto area. The successors of East Chinatown were largely Vietnamese, of whom many were ethnic Chinese (Wang, 1996). Since the early 1990s, mainland China has become the major source of new immigrants settling in Toronto. Although many of these new immigrants settled directly in Toronto's suburban areas, some continued to settle in the two Chinatowns in the inner city. In recent years, as reported by interviewees, an increasing number of stores are operated by Mainland Chinese immigrants in East Chinatown, which target Mandarin speaking customers.

According to interviewed merchants and shoppers/visitors, East Chinatown businesses mainly serve the local Chinese residents. Chinese respondents to the intercept survey who resided in East Chinatown shopped there because of convenience. They also considered the retail strip a social place to interact with other people because of its connection to bus stations, a public library, and a large nearby urban park. Other Chinese or non-Chinese visitors to the area were mainly from the Greater Toronto Area (GTA) and their visits were infrequent. Most of these visitors reported they did not generally shop in East Chinatown due to the lack of appeal of the low-end products and the lack of variety in the merchandise. Merchants also acknowledged that the area is less attractive to tourists than Downtown Chinatown because of the same reason. Annual community events, however, such as the Dragon Fest and Canada Day Celebration 
organized by East Chinatown merchants serve as major social and cultural venues that attract residents and visitors from outside of the neighbourhood.

\section{Economic Processes}

The business profile of East Chinatown and interviews with local merchants and shoppers confirm that businesses in the area mainly cater to a local co-ethnic customer base. As the CSCA data show in Table 2, East Chinatown mainly features food-related businesses $(39.6 \%)$ and other services (36.9\%). Food stores and restaurants are the dominant business types and are a typical Chinatown attraction. The personal/business service sector, for the most part, serves local residents. The rest of the businesses $(23.5 \%)$ are retailers providing low-value products, such as affordable clothes and household items that do not appeal to a larger customer base. The annual vacancy rates in East Chinatown from 2000-2009 were higher than those of the City of Toronto, with a ten-year average of $14.0 \%$ vs. $9.8 \%$. This suggests a declining business environment.

Table 2: Comparing Business Profiles (2000-2009) of the Three Neighbourhoods

\begin{tabular}{|c|c|c|c|}
\hline $\begin{array}{l}\text { Business Composition (2000- } \\
2009 \text { average) }\end{array}$ & East Chinatown & Gerrard India Bazaar & Corso Italia \\
\hline Food Related (\%) & 39.6 & 36.8 & 26.9 \\
\hline Food services & 19.3 & 22.2 & 20.7 \\
\hline Food stores & 20.3 & 14.5 & 6.2 \\
\hline Other Retail (\%) & 23.5 & 42.3 & 46.1 \\
\hline \multicolumn{4}{|l|}{ Top categories } \\
\hline Apparel & 3.1 & 18.2 & 33.7 \\
\hline Household \& appliance & 4.9 & 5.2 & 1.5 \\
\hline Jewelry & & 8.4 & \\
\hline
\end{tabular}




\begin{tabular}{|l|r|r|r|r|}
\hline $\begin{array}{l}\text { Business Composition (2000- } \\
\text { 2009 average) }\end{array}$ & \multicolumn{1}{|c|}{ East Chinatown } & Gerrard India Bazaar & \multicolumn{2}{|c|}{ Corso Italia } \\
\hline General merchandise & 2.6 & 20.9 & 27.0 \\
\hline Other Services (\%) & 36.9 & 2.3 & 5.0 \\
\hline Top categories & 11.4 & 1.8 & 4.1 \\
\hline Hair \& beauty & 5.6 & 1.2 & 2.4 \\
\hline Health & 1.6 & & 250 \\
\hline $\begin{array}{l}\text { Motion picture \& video } \\
\text { distribution }\end{array}$ & 150 & 140 & \\
\hline Banks & & & \\
\hline Number of Businesses (approx.) & & & \\
\hline
\end{tabular}

Source: CSCA Business Survey Data, 2000-2009

The East Chinatown business community, represented by a voluntary business association, the Chinese Chamber of Commerce, East Toronto (CCCET), has demonstrated a strong desire to save their neighbourhood. Established in 1983, the CCCET now has more than 300 members. It has been a major force encouraging local merchants to work together to revitalize the declining business environment in East Chinatown. Their leadership is exemplified by their efforts over a decade to build a Chinese archway to promote East Chinatown, which will be discussed in following section.

\section{Physical Processes}

In 1998, the CCCET initiated the construction of the Chinese Archway (Paifang) (Figure 3) in East Chinatown to mark its border. Chinese Archways usually serve as a popular means of 
translating Chinese culture to Western populations. They are found in Chinatowns worldwide and are often initiated and promoted by the local community (Lai, 1988).

Figure 3: The Chinese Archway in East Chinatown

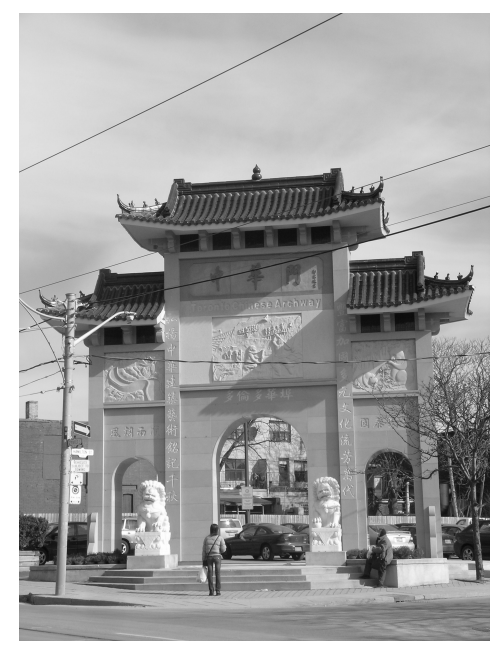

The CCCET initiated the archway project to revitalize the business environment, boost tourism, and help the area compete with other Chinese commercial areas. The CCCET's top priority was to open political channels with three levels of government (federal, provincial, and municipal) and to build the necessary financial and political resources for construction. According to interviewees, business leaders of the Association had the know-how to exert influence on local politicians, as they believed "CCCET has the responsibility to work with City Officials in order to serve the community well." Although many local merchants encountered language barriers, they were able to rely on a former administrative assistant at the city councilor's office (who speaks fluent Cantonese, Mandarin, and English) to keep communication channels open. Over the years, the CCCET has built a strong community alliance with the City of Toronto. As one interviewed planner commented: 
They've [the CCCET] had a number of businessmen who really have a vision, and they're working together to try to promote their area ... And I also think that they make that lead to ... getting the city to help them, tapping into the expertise we offer ... using what is relevant to what they want to achieve there.

According to the interviewed business leaders, the CCCET also sought help from the Chinese government, which donated building materials for the construction of the archway as a way to sustain Chinese cultural heritage and reinforce its national identity among the Chinese diasporas. ${ }^{6}$ With financial and political support from the City of Toronto and fundraising efforts led by the CCCET, the archway was built in 2009, 11 years after its inception. The City and the CCCET each committed half million Canadian dollars for construction.

Interviewed business leaders viewed the Archway as a new symbol of the East Chinatown community and believed that it would attract more visitors to the area and make members of the Chinese community feel more at home. They argued that in spite of its large Chinese immigrant community, Toronto was one of the few cities in the world that did not have an archway structure to represent the Chinese community and define the place of Chinatown. To most of merchants, the Chinese business hub created by East Chinatown was not only important to their own business, but also good for the Chinese community and beneficial to the general population of Toronto. These interviews made it clear that East Chinatown was a 'place' in which local entrepreneurs wanted to continuously invest, improve, and express their ethnic pride.

However, some interviewed merchants did not consider the archway to be the main priority of the area. One said, "it can't make fundamental changes... [and] has nothing to do 
directly with each individual storefront. It's just advertising." These merchants reported that they were more concerned about many unresolved issues affecting local businesses, such as cleanliness, parking, safety, sidewalk condition, rundown streetscapes and deteriorating building stock in the area. According to them, these problems have prevented the area from sustaining its business vitality and improving its appeal to a larger customer base. The interviewees complained that "East Chinatown is always a mess," remarking, "How can you construct an archway and the area looks like a garbage town?" and "[they] never see a [tourist] bus come here ... because [there is] nothing to see."

Today's immigrants tend to bypass the inner city and settle directly in the suburbs (Li, 2009), while earlier immigrants and their children are also moving out of Toronto's downtown core (Wang, 1999). The resulting loss of potential customers has made it difficult for East Chinatown to compete with either the more famous, tourist-flooded Downtown Chinatown or the mushrooming suburban satellite Chinatowns found in Chinese shopping plazas and malls. Despite the fact rents in East Chinatown are as much as three times cheaper than in other downtown areas according to interviewed merchants, vacancy rates have been higher than the city average for more than a decade based on the CSCA business data. East Chinatown's decline was exacerbated when a fire broke out in July 2013 destroying a 100-year-old landmark building at the major intersection of the area and adding uncertainty to the revitalization of this area.

\section{Gerrard India Bazaar: A South Asian Shopping Destination in the Making}

The Gerrard India Bazaar is located approximately 1.5 kilometers east of East Chinatown on Gerrard Street East between Greenwood and Coxwell Avenues. It traces its origins to 1972, when 
Gian Naaz, an Indian immigrant, purchased the Eastwood Theatre, and turned it into the Naaz Theatre to show Hindi ('Bollywood') films (Bauder and Suorineni 2010; Hackworth and Rekers 2005). Other South Asian businesspersons were attracted to the area because moviegoers wanted to shop and eat in the area, and rents were inexpensive. Over time, this commercial strip once dominated by Anglo-Saxon and Greek stores was replaced by South Asian sweet shops, sari stores, restaurants, record shops, and grocery stores catering to the booming South Asian market (Figure 4). According to Kaplan, this type of spatial concentration of ethnic businesses "can act as a focal point serving a residentially dispersed ethnic community" (1998: 494). It has positive effects on ethnic businesses despite lacking the support of a co-ethnic residential population.

Figure 4: Gerrard India Bazaar Streetscape

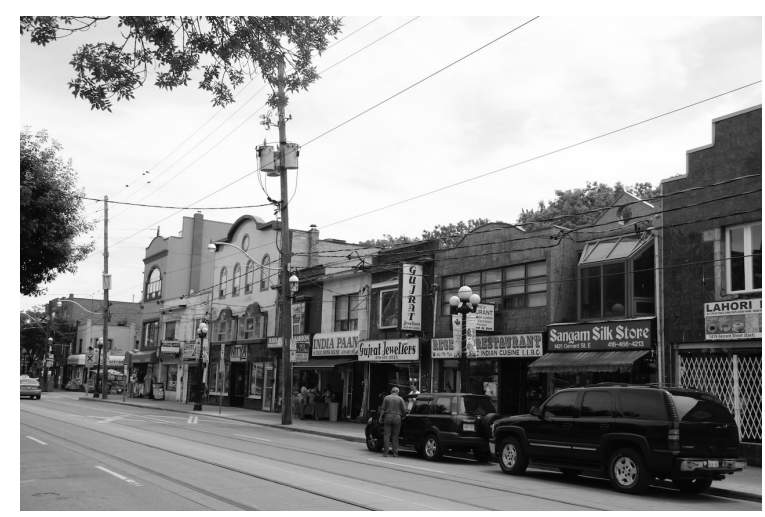

\section{Social Processes}

Unlike most traditional ethnic commercial strips that are "normally associated with the point of entry of an immigrant group" and initially serve "the needs of the immediate neighborhood" (Jones 2000: 415) as is the case in East Chinatown and Corso Italia, the local South Asian residential population has not been large enough to support the businesses in the India Bazaar. South Asians comprise only $9.8 \%$ of the population in the area; less than the city 
average (12.0\%). The Chinese population has the highest concentration in the neighbourhood compared with other groups: $13.6 \%$ by home language, $22.1 \%$ by ethnic origin, and $20.3 \%$ by visible minority group (City of Toronto 2008b). In fact, the residential and business concentrations of Toronto's South Asian population are higher in the inner and outer suburbs of Toronto, such as Scarborough, Brampton, Markham, and Mississauga, than in the inner city (Qadeer et al. 2010). Consequently, the India Bazaar serves a regional community, rather than a local one. The area emerged and continued to develop differently than traditional ethnic enclaves where "neighbourhoods [are] dominated by a particular ethnic group and marked by institutions reflecting its cultural values and symbols" (Qadeer et al. 2010: 318).

There is a large spectrum of differences among the South Asian entrepreneurs in the Bazaar in terms of sub-cultures, sub-ethnicities, and religions. As reported by the merchants and the community agency staff interviewed, the entrepreneurs in this area originate not only from the Indian subcontinent countries, but also from other parts of the world. People from these ethnically diverse communities also speak different languages and dialects, and follow diverse religions. Compared with the group in East Chinatown, individual businesses in the India Bazaar tend to adopt an independent rather than collective approach. This dissimilarity may be related to sub-group differences. Also, interviewees indicated that many South Asian merchants have previous business experience; together with their advantage in the English language, this may have helped merchants establish their own enterprises without relying on group resources or political support.

Similar to East Chinatown, cultural festivals have been a common part of the social processes that defined the retail area as a place. According to most interviewees, hosting South 
Asian community festivals has not only been a means of introducing the diverse South Asian cultures to the larger community, but also a means of reconciling its many sub-cultural groups, especially along religious lines. Local merchants organize a series of annual festivals that celebrate the South Asian cultures, such as the Eid Festival (End of Ramadan for Muslims), the Baisakhi Festival (a Punjabi and Sikh celebration of spring in April), the Diwali Festival (Festival of Lights for Hindus), and finally Christmas and New Year celebrations for the Christian community. The Festival of South Asia is a general event that draws thousands of visitors each year to explore and enjoy South Asian food, arts, and cultures.

From the South Asian shoppers' perspective, the India Bazaar provides almost everything they need in terms of speciality goods. Non-South Asian patrons said that they were attracted by the exotic atmosphere of the India Bazaar and the food. Only two out of the 10 respondents lived close by and they did not shop often in the area.

\section{Economic Processes}

As indicated by the area's business profile and echoed by most of the interviewed entrepreneurs and shoppers, the predominance of retail (42.3\%) and food businesses (36.8\%) in the Bazaar suggests a tendency to create a 'one-stop shopping destination' appeal that targets a regional clientele beyond geographical boundaries and ethno-cultural lines (Table 2). Among the foodrelated businesses, food services such as restaurants, bars, and takeout-style shops represent a higher proportion than food stores (groceries, bakeries, fruit markets, superstores). In the retail sector, apparel and jewelry stores are most prominent, accounting for nearly one-quarter of all businesses. The personal/business services category accounts for only $20.9 \%$ of the market. The 
overall vacancy rate of the area from 2000-2009 was slightly lower than that of the city as a whole (9.1\% vs. $9.8 \%)$.

The Gerrard India Bazaar was approved as a Business Improvement Area (BIA) in 1982. A BIA is a voluntary association of local business persons and property owners within a specified boundary, who work together in partnership with the city to improve and promote their business area. The City of Toronto collects a special tax levy from BIA businesses and the funds are used for purposes such as streetscape improvement, event planning, marketing, and promotional campaigns. It also provides 50/50 matched capital funding for streetscape improvements, such as façade upgrade. The world's first BIA was implemented in Toronto in 1970, and Toronto currently has 81 BIAs, seven of are named for the ethnic groups they originally represented (Greektown, Korea Town, Chinatown, Little Italy, Little Portugal, Corso Italia, and Gerrard India Bazaar) (City of Toronto, 2015). Since the 1980s, the Bazaar businesses have utilized the BIA program to improve and promote the area. Earlier initiatives included designing a BIA logo, promoting the name 'India Bazaar' in the media, organizing local events and small business workshops, and improving street lighting. Interviewed merchants also acknowledged the importance of forming a BIA to nurture the business environment collectively and build a strong partnership with the city.

\section{Physical Processes}

Significant physical streetscape improvements have yet to be conducted in the Bazaar in part. Merchants have, however, expressed interest in developing the ethnic identity of the area through physical forms, similar to the Chinese Archway approach (Kumar and Martin, 2004). 
While Toronto's standardized BIA program generally offers beautification and improvement templates, such as façade upgrade, street murals, or landscaping (Author 2015), it does not provide for cultural expressions such as those reflected in the social and physical features of local businesses. The latter are initiated by individual entrepreneurs. For example, the street life in the Bazaar resembles a typical South Asian merchant area with corn stands on the sidewalks, spice shops, and sarees and jewelry in window displays (Figure 5). One restaurant used picnic tables under colourful sari-tents in a large patio to provide outdoor dining space in the summer, recreating a traditional scene of a South Asian street eatery. Some informal business practices, such as converting portable trailers into indoor restaurant spaces, have even clashed with municipal fire and safety standards and have been penalized by the City (Author 2013). Several buildings in the west section of the BIA were painted in bright colours to add a fresh look to the strip because business owners wanted to "reflect the joys and the celebration [as] they believe life is beautiful." Interviewees believed that the retail strip provided each entrepreneur with space to express their cultural identity, which was also beneficial to their own businesses.

Figure 5: Corn Stand (Left) and Window Displays (Right) in Gerrard India Bazaar
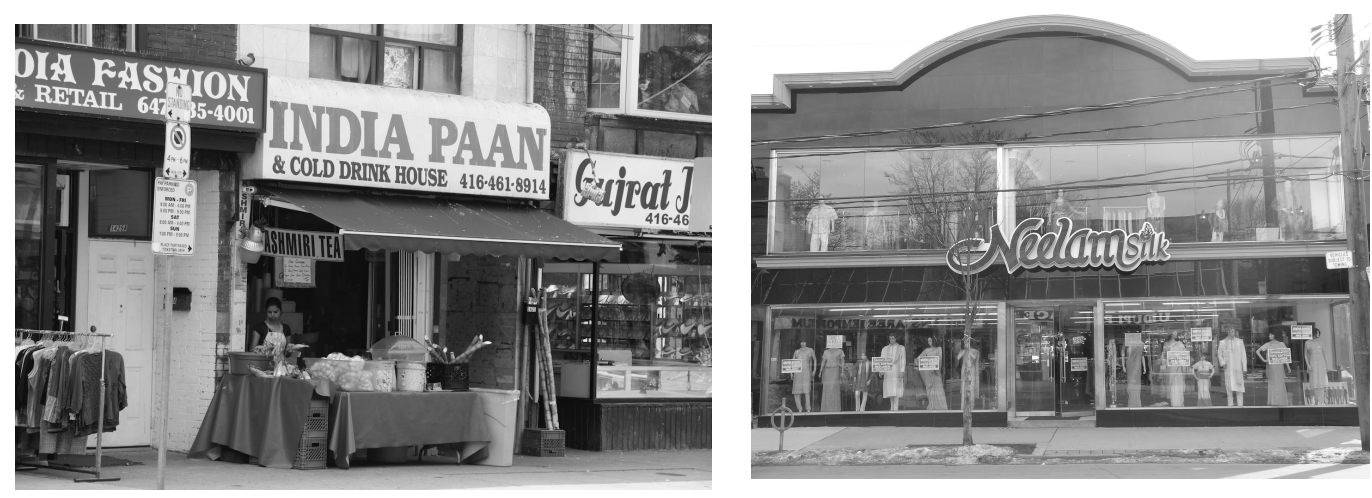
Lack of parking space is one physical constraint of the retail strip. As one interviewed city planner commented, unlike traditional ethnic enclaves, the Bazaar was not originally “intended to be a commercial strip. So it's not set up like other commercial strips in the city ... [For the most part] they have parking on the side streets." Many customers drive to this area from other places. Without sufficient parking capacity in the area, they are forced to park on residential streets or tow-away zones, causing traffic congestion and frustration among customers, merchants, and residents. As a result, the BIA has had to hire staff to patrol the strip and direct parking.

\section{Corso Italia: A Diverse Neighbourhood under Ethnic Succession}

Corso Italia is located on St. Clair Avenue West from Westmount Avenue, just east of Dufferin Street, to slightly west of Lansdowne Avenue. Having been recognized as one of two existing 'Little Italies' in Toronto, Corso Italia has experienced remarkable ethnic succession and transformation over the past 60 years. In the 1950s, the area was known as Little Britain; most of the stores then were British- or Jewish-owned (Buzzelli 2001). With the influx of Italian immigrants to Toronto after the Second World War, this area became a destination for the Italian immigrant population, many of whom moved beyond their original settlements in the other Little Italy along College Street, and was dominated by Italian businesses from the 1960s to the 1980s (Byers and Myrvold 1999). However, since the 1970s, the number of Italian immigrants to Canada has dropped and many members of the Italian community have moved to Toronto's outer suburbs. The area has become a reception destination for Portuguese immigrants, as well as immigrants from Latin America and Asia (Figure 6). 
Figure 6: Corso Italia Streetscape

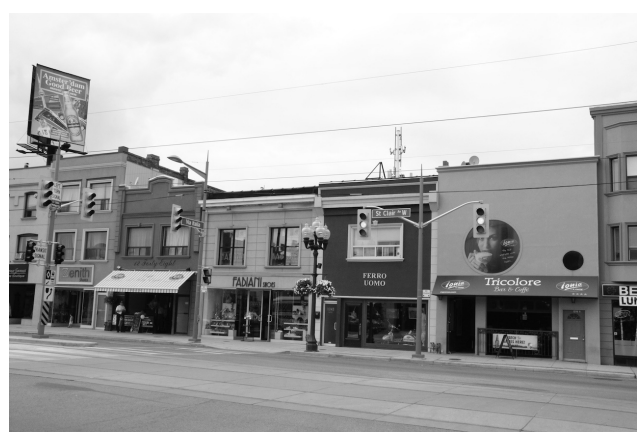

\section{Social Processes}

Based on the 2006 Census, the Portuguese population has replaced the Italians as the largest group in the Corso Italia area by home language (16.7\% vs. 10.9\%) and by ethnic origin (30.7\% vs. 27.6\%). Latin Americans (8.8\%) and Blacks (4.8\%) were the two largest visible minority groups in the area (City of Toronto 2008c). Unlike the neighbourhoods of East Chinatown and the Indian Bazaar, where subgroups of Asians (especially Chinese) are generally the predominant visible minority groups, the Corso Italia neighbourhood represents a more multi-ethnic mixture.

The merchants also represent a mixture of ethno-cultural backgrounds. Interviewees estimated that approximately $60 \%$ of storekeepers are of Italian origin, $20 \%$ of Portuguese origin, and $20 \%$ of 'other' origins. The Italian identity of the neighbourhood has diluted as a result, although the area maintains its central status in Toronto's Italian community. Six out of the eight interviewed entrepreneurs were in favour of a European theme or a neutral appeal to attract more customers from different backgrounds. Similar thoughts were behind the name change of the area's annual street festival. As early as the 1950s, businesses in the area had "the Festa" (an Italian word for festival), a celebration sponsored by the local churches (Byers \& Myrvold, 1999). Since 1997, the annual street festival has been called "the Fiesta" (a Spanish word for 
festival) and is programmed to celebrate the cultural traditions of Italians, Portuguese, Hispanics, and other Europeans. According to merchants and a former city councilor interviewed, the name change reflects the increasing influence of the Hispanic community from Latin America to the Corso Italia area.

The intercept surveys revealed that many shoppers were local residents who are regulars at the local stores. A few were from the suburban municipalities outside the City of Toronto and shopped in Corso Italia for quality specialty products, such as shoes and wedding dresses. Respondents commented that the population of the area was becoming more mixed with newcomers of Asian and Latin American origins. This growing diversity was reflected in the local businesses that provide products catering to a wider range of groups. The retail strip is evolving into a place for both local and regional customers.

\section{Economic Processes}

Unlike the Little Italy in downtown Toronto, which is dominated by restaurants, the Corso Italia BIA (established in 1984) promotes the area "as a less tourist-oriented alternative" and claims that "the retail mix is much more affordable and comprehensive for residents" (Hackworth and Rekers, 2005: 228). Corso Italia specializes in retail (46.1\%), especially high-end fashion stores that draw customers from all over the city. Its food-related businesses (e.g., restaurants, bakeries, grocery stores) and other services are more locally oriented, each consisting of just over one-

quarter of the businesses (Table 2). Hackworth and Rekers noted, "restaurants in Corso Italia are generally less expensive, older, and more dependent on a local consumer base than those in the more commercially successful Little Italy to the south" (2005: 233). The eight interviewed 
merchants who operated bakeries, restaurants, groceries, gift shops, and clothing stores also confirmed that each sector has a different local or regional customer base. This 'dual approach' differs from the other cases: in East Chinatown, businesses mostly serve the local residential population, and in the India Bazaar, they target a more regional customer base and the tourist market. A lower-than-city-average vacancy rate from 2000-2009 (5.9\% vs. 9.8\%) illustrates Corso Italia's stable business environment.

The Corso Italia BIA has primarily used its funds to focus heavily on streetscape improvement, seasonal decorations, event planning, marketing, and advertising. One subject that was being discussed among merchants at the time of the interviews was whether the BIA's name 'Corso Italia' should be used as a collective image of the business community, as it does not correspond with the demographic transition and diversification of the area. Merchants expressed that they "don't want to lose that [Italian] flavour ... But it's nice to have a sprinkling of nationalities." Although the name, Corso Italia, remains, merchants have tended to adopt a multiethnic or more neutral approach in BIA business matters for the purpose of marketing and advertising. Local businesses promote the area with a toned-down Italian theme and a more generally accepted multi-ethnic image through the merchandise they carry and the services they provide. For example, the BIA's website promotes Corso Italia as "where the roots of European culture remain strong and vibrant" and "home to authentic Italian and multi-cultural heritage in Toronto" (Corso Italia BIA, 2015).

\section{Physical Processes}


There are also physical attributes that reflect the area's transformation from 'Little Britain.' Typical examples include buildings that were adapted to meet the needs of ethnic businesses, such as the removal of vestibules to make way for storefront café windows. Funded under the Façade Improvement Program instituted by the Economic Development Office of the City of Toronto, Corso Italia merchants have revamped their store façades to reflect an elegant shopping atmosphere with a strong European flavour. Most of the interviewees stressed that their store façade does not need "a stronger Italian image" nor should it "keep that Italian identity alive."

In addition, the Italian merchants in particular are pushing the BIA to get involved in public matters, for example in their fight against the City of Toronto in a streetcar right-of-way dispute. In 2003, the City of Toronto decided to build raised tracks for a streetcar right-of-way in the middle of the St. Clare Avenue West (Figure 7). Local merchants expressed concern about the potential loss of sidewalk width and trees, and on-street parking, because the area has a tradition of sidewalk cafés and outdoor patios, with trees and pedestrian activities on the street, reflecting an Italian or, more generally, European city lifestyle that attracts a regional draw of customers. Among those BIAs that are most affected by the right-of-way, merchants in Corso Italia were the loudest in their opposition to the plan and they exerted strong influence on the dispute.

Figure 7: The Streetcar Right-of-way along the St. Clare Avenue West

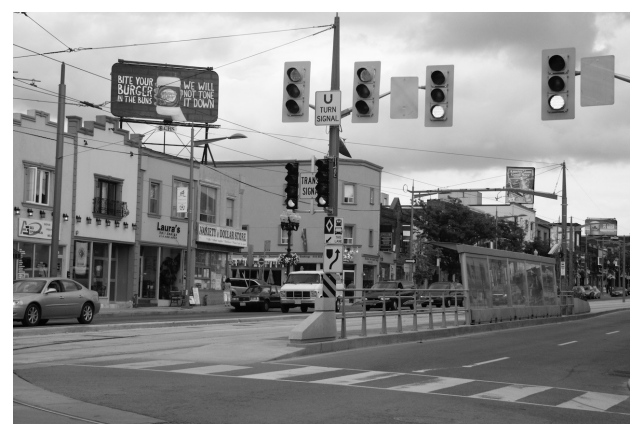


Local merchants actively participated in numerous public consultation meetings and were highly aware of the importance of building community partnerships with the City and other stakeholders. They even hired architects to develop an alternative design to promote a more pedestrian-friendly streetscape. However, their proposal was rejected by the City. When no consensus was reached, local merchants and other residents confronted the City of Toronto in court. Although the court ruled in favor of the City, the Corso Italia business community demonstrated itself to be proactive, mobilized, and powerful in taking a leading role, which in turn, brought the local councilor on board in their fight. Compared with the cases in East Chinatown and the Gerrard India Bazaar, merchants in Corso Italia have had higher level of public involvement and have been most proactive on local development issues.

\section{Discussion and Conclusion: How Do Ethnic Entrepreneurs Define and Affect These}

\section{Neighbourhoods?}

As illustrated in the case studies, the three neighbourhoods were all developed in different ways, socially, economically, and physically, with various forms of ethnic succession, group characteristics, uses of public spaces, market sizes, business organizations, identity expressions, physical development stages, and spatial relationships between ethnic businesses and the coethnic residential population. The trajectories of these neighbourhoods reveal that ethnic retail development is fluid. No single growth pattern emerged, given the wide diversity among ethnic groups. However, in all three cases, ethnic retailing resulted in significant transformation of the neighbourhood, and ethnic entrepreneurs were the driving force behind the social, economic, and physical processes of transformation. 


\section{$\underline{\text { Social processes }}$}

Ethnic entrepreneurs did not make typical ethnic enclaves, but have helped create and promote a strong sense of community and social identity in the studied neighbourhoods. All three neighbourhoods differ from - or are even opposite to - stereotypes about ethnic enclaves that usually are "dominated by a particular ethnic group" (Qadeer et al. 2010: 318) and marked by "institutional completeness" (Breton 1964: 194). ${ }^{7}$ None of the three neighbourhoods has a majority ethnic group residing in the area. In the extreme case of the India Bazaar, there is not even a significant co-ethnic residential population to support South Asian businesses or achieve more institutional completeness. Additionally, the social composition of each neighbourhood's population reveals intra-group and inter-group diversity, with different group characteristics and different immigrant settlement histories and processes, contributing to the social transformations and successions of the neighbourhoods.

Regardless of the various degrees of institutional completeness in each community, these ethnic retail strips are more than specialty retail destinations. For immigrants, these neighbourhoods can serve as ports of entry or community places where they share similar cultural experiences and find attachment within the areas. For the community at large, the areas showcase diverse social and cultural heritages and become attractions for people near and far. This type of community function, integrated with shopping and cultural experiences, might not occur in other mainstream retail strips or shopping malls, or if an area lacks ethnic business concentration. Despite sub-group differences along cultural, linguistic, and religious lines, ethnic 
entrepreneurs in each of the three areas collectively create and promote the social identity of the retail strip through a variety of business activities and cultural events.

\section{Economic processes}

Overall, the ethnic entrepreneurs have maximized spatial capital that benefits local economy and defines a sense of place. The case studies demonstrate that ethnic entrepreneurs maximize spatial capital through business concentration to define, maintain, or intensify the ethnic commercial identity of the area. The concept of spatial capital as suggested by Kaplan and Li (2006) refers to spatial concentration of businesses as a resource that benefits ethnic economies and contributes to place identity. The neighbourhoods discussed in this paper are notable for their concentration of ethnic businesses, regardless of the development histories of the neighbourhoods or the spatial relationships between the ethnic businesses and the co-ethnic residential population. Ethnic entrepreneurs diversify the retail environments by carrying specialty cultural goods and services. Each studied area features specific business components to target a local and/or regional customer base, such as food stores and other services in East Chinatown, apparel and jewelry stores in Gerrard India Bazaar, and high-end fashion stores in Corso Italia.

Interviewed merchants preferred the spatial concentration of co-ethnic businesses because it maximizes ethnic resources and promotes one-stop shopping for customers. Spatial concentration also benefits the image of the area that the local business organizations such as the CCCET and the BIAs want to invest and improve.

\section{Physical processes}


Despite significant inter-group differences, ethnic entrepreneurs contribute to the physical development of the ethnic retail strips and the manifestation of ethno-cultural identity through a variety of physical means, such as signage, window display, store facades, street space, and architectural structures.

Each studied neighbourhood has experienced remarkable ethnic succession over the years. When ethnic succession occurs, the demographic composition, business profile, and identity of the neighbourhood change accordingly. The development of the Gerrard India Bazaar and its subsequent evolution as a South Asian business focal point also demonstrates that ethnic entrepreneurs sometimes play a more important role than the residential population in defining the characteristics and identity of the area.

Here, inter-group differences in terms of ethnicity, cultural preferences, group characteristics, and business organization and strategy help explain how spatial capital comes into play in ethnic businesses, and lead to the physical development of different retail places. The three ethnic groups have varying spatial needs, which are reflected in different business practices and uses of public spaces. For example, vertical signboards and sidewalk sales of fresh produce are common features in Chinatowns, and East Chinatown is no exception. The construction of the Chinese Archway represented the strong desire of the business community to express ethnic pride and save and redefine the neighbourhood. Sidewalk spaces in the India Bazaar feature colourful window displays and chaat stands. In the case of Corso Italia, the streetcar right-ofway dispute illustrates the strong desire of local merchants to preserve European-style street space on the retail strip. 
The inter-group dynamics also confirm that ethnic differences play a role in determining the development processes and physical outcomes of ethnic retail neighbourhoods. For example, despite language barriers, East Chinatown merchants rely more on group solidarity and political support in their revitalization efforts. The South Asian entrepreneurs of the Gerrard India Bazaar represent a range of religious and linguistic groups and thus are more independent, relying less on group resources, although the BIA program helps them work together. The business community of Corso Italia has a higher level of institutional completeness and public involvement, which enable business owners to act proactively and engage in public matters that affect the physical shape of the neighbourhood.

\section{Implications for municipalities}

These three cases reveal how the business community was involved in the development of public spaces and municipal relations. The inner-city shopping strips were mainly unplanned public spaces that have developed incrementally over time. The organic manner in which they grow allows room for businesses to change and for continuous development in the area. Ethnic entrepreneurs who own businesses on the strips are, to various degrees, involved in the development processes of the areas - and their involvement ultimately accounts for physical changes in the areas. Because the public space engages multiple interests, dialogue is ongoing between the city and the business community.

These research findings reveal several implications for municipalities and planning practices. First, municipalities should avoid stereotypes about ethnic enclaves, because different social, economic, and physical components affect the making of an ethnic retail place. More 
resources including funding and policy are needed to explore the dynamics of ethnic retail neighbourhoods and support their long-term sustainability. Second, municipalities should consider the diverse needs of ethnic entrepreneurs and the important roles they can play in making retail places. City planners, as the professionals at the forefront of urban development, are responsible for place-related issues such as land use, streetscape, parking capacity, tourism development, neighbourhood revitalization, and community building. During these planning processes, an understanding of local context and community needs is extremely important to inform planning policies and interventions. Finally, due to the complexity of ethnic entrepreneurship and the profound differences among ethnic groups in the development processes of diverse ethnic retail places, municipalities need to be aware that there is no template solution to the long-term development of these places. Different ethnic groups leave different imprints on the retail areas. Therefore, creative municipal programs should acknowledge that each ethnic group has distinct identities, cultural preferences, spatial needs, business organizations and strategies, immigration histories, and levels of institutional completeness, and ensure that ethnic entrepreneurs are continually involved in the making and marking of ethnic retail places.

\section{References}

Agnew J (1987) Place and Politics: The Geographical Mediation of State and Society. London: Allen and Unwin. 
Agnew J (2011) Space and Place. In J Agnew and D Livingstone (Eds.). Handbook of Geographical Knowledge. London: Sage, pp. 316-331.

Bauder H, Suorineni A (2010) Toronto's Little India: A Brief Neighbourhood History. Digital Commons@Ryerson.Accessed November 12, 2012.http://digitalcommons.ryerson.ca/ immigration/3

Bonacich E, Modell J (1980) The Economic Basis of Ethnic Solidarity: Small Businesses in the Japanese American Community. Berkeley, CA: University of California Press.

Breton R (1964) Institutional Completeness of Ethnic Communities and the Personal Relations of Immigrants. The American Journal of Sociology 70 (2): 193-205.

Buzzelli M (2001) From Little Britain to Little Italy: An Urban Ethnic Landscape Study in Toronto. Journal of Historical Geography 27(4): 573-587.

Byers N, Myrvold B (1999) St. Clair West in Pictures: A History of the Communities of Carlton, Davenport, Earlscourt, and Oakwood (2nd ed.). Toronto: Toronto Public Library.

City of Toronto (2008a) South Riverdale Neighbourhood Profile. Accessed August 30, 2012. http://www1.toronto.ca/wps/portal/contentonly? vgnextoid=1e68f40f9aae0410VgnVCM10000071d60f89RCRD

City of Toronto (2008b) Greenwood-Coxwell Neighbourhood Profile. Accessed August 30, 2012. http://www1.toronto.ca/wps/portal/contentonly? vgnextoid=1e68f40f9aae0410VgnVCM10000071d60f89RCRD

City of Toronto (2008c) Corso Italia-Davenport Neighbourhood Profile. Accessed August 30, 2012. http://www1.toronto.ca/wps/portal/contentonly? vgnextoid=1e68f40f9aae0410VgnVCM10000071d60f89RCRD 
City of Toronto (2015) Toronto's Business Improvement Areas. Accessed April 30, 2015. http:// www1.toronto.ca/wps/portal/contentonly? vgnextoid=673032d0b6d1e310VgnVCM10000071d60f89RCRD

Collins, J (2006) Ethnic Diversity and the Ethnic Economy in Cosmopolitan Sydney. In D Kaplan and W Li (Eds.), Landscapes of the Ethnic Economy. Lanham: Rowman and Littlefield, pp. 135-148.

Corso Italia BIA (2015) Welcome to Corso Italia! Accessed December 1, 2014. http:// www.torontocorsoitalia.com/index.htm

Government of Canada (2015) Employment Equity Act. Accessed May 19, 2015. http://lawslois.justice.gc.ca/PDF/E-5.401.pdf

Hackworth J, Rekers J (2005) Ethnic Packaging and Gentrification: The Case of Four Neighborhoods in Toronto. Urban Affairs Review 41(2): 211-236.

Hartman S (2014, August 10) A New Life for Refugees, and the City They Adopted. The New York Times. http://www.nytimes.com/2014/08/11/nyregion/a-new-life-for-refugees-andthe-city-they-adopted.html?_r=0

Jacobs J (1961) The Death and Life of Great American Cities. New York: Vintage.

Jones K (2000) Dynamics of the Canadian Retail Environment. In T Bunting and P Filion (Eds.), Canadian Cities in Transition. New York: Oxford University Press, pp. 404 - 422.

Kaplan D (1998) The Spatial Structure of Urban Ethnic Economies. Urban Geography 19(6): 489-501.

Kaplan D, Li W (2006) Introduction: The Places of Ethnic Economies. In D Kaplan and W Li (Eds.) Landscapes of the Ethnic Economy. Lanham: Rowman and Littlefield, pp. 1-14. 
Kloosterman R, Rath J (2001) Immigrant Entrepreneurs in Advanced Economies: Mixed Embeddedness Further Explored. Journal of Ethnic and Migration Studies 27: 189-201.

Kloosterman R, Van der Leun J (1999) Just for Starters: Commercial Gentrification by Immigrant Entrepreneurs in Amsterdam and Rotterdam Neighbourhoods. Housing Studies 14(5): 559-677.

Kumar S, Martin G (2004) A Case for Culturally Responsive Urban Design. Ontario Planning Journal 19(5): 5-7.

Lai DC (1988) Chinatowns: Towns Within Cities in Canada. Vancouver: University of British Columbia Press.

Li W (1998a) Anatomy of a New Ethnic Settlement: The Chinese Ethnoburb in Los Angeles. Urban Studies 35(3): 479-501.

Li W (1998b) Los Angeles's Chinese Ethnoburb: From Ethnic Service Center to Global Economy Outpost. Urban Geography 19(6): 502-517.

Li W (2009) Ethnoburb: The New Ethnic Community in Urban America. Honolulu: University of Hawaii Press.

Light I (1972) Ethnic Enterprise in America: Business and Welfare among Chinese, Japanese and Blacks. Berkeley: University of California Press.

Light I, Sabagh G, Mehdi B, Der-Martirosian C (1994) Beyond the Ethnic Enclave Economy. Social Problems 41(1): 65-80.

Light I, Rosenstein C (1995) Expanding the Interaction Theory of Entrepreneurship. In A Portes (Ed.), The Economic Sociology of Immigration: Essays on Networks, Ethnicity, and Entrepreneurship. New York: Russell Sage Foundation, pp. 166-212. 
Light I, Gold SJ (2000) Ethnic Economies. San Diego: Academic Press.

Lin J (2011) The Power of Urban Ethnic Places: Cultural Heritage and Community Life. New York: Routledge.

Lo L, Preston V, Wang S, Reil L, Harvey E, Siu B (2000) Immigrants'Economic Status in Toronto: Rethinking Settlement and Integration Strategies. Working Paper No.15, Toronto: Joint Centre of Excellence for Research on Immigration and Settlement (CERIS).

Loukaitou-Sideris A (2002) Regeneration of Urban Commercial Strips: Ethnicity and Space in Three Los Angeles Neighborhoods. Journal of Architectural and Planning Research 19(4): $334-50$.

Lynch K (1960) The Image of the City. Cambridge Massachusetts: MIT Press.

Marshall C, Rossman G (2011) Designing Qualitative Research (5th Ed.) Los Angeles: Sage.

Portes A, Manning R (1986) The Immigrant Enclave Theory and Empirical Examples. In S Olzak and J Nagel (Eds.), Competitive Ethnic Relations. New York: Academic Press, Inc, pp. 47-68.

Preston J (2013) Ailing Midwestern Cities Extend a Welcoming Hand to Immigrants. The New York Times. October 6. Accessed April 30, 2015. http://www.nytimes.com/2013/10/07/us/ ailing-cities-extend-hand-to-immigrants.html

Project for Public Spaces (2014) What is Placemaking? Accessed March 15, 2014. http:// www.pps.org/reference/what_is_placemaking/

Qadeer M, Agrawal S and Lovell A (2010) Evolution of ethnic enclaves in the Toronto Metropolitan Area. 2001-2006. Journal of International Migration and Integration 11 (3): 315-339. 
Rath J (2007) The Transformation of Ethnic Neighbourhoods into Places of Leisure and

Consumption. Working Paper 144. San Diego: Centre for Comparative Immigration Studies, University of California.

Rath J, Kloosterman R (2000) Outsiders' Business: A Critical Review of Research on Immigrant Entrepreneurship. International Migration Review 34: 657-681.

Robertson K (1997) Downtown Retail Revitalization: A Review of American Development Strategies. Planning Perspectives 12:383-401.

Robertson K (2002) Main Street Partnering: A Key to Successful Downtown Revitalization. IEDC Economic Development Journal 1(4):53-59.

Silberberg S, Lorah K, Disbrow R, Muessig A (2013) Places in the Making: How Placemaking Builds Places and Communities. Cambridge, MA: MIT Department of Urban Studies and Plannning.

Statistics Canada (2013) Immigration and Ethnocultural Diversity in Canada: National Household Survey, 2011. Accessed March 15, 2014. http://www12.statcan.gc.ca/nhs-enm/ 2011/as-sa/99-010-x/99-010-x2011001-eng.cfm

Statistics Canada (2015) Visible Minority of Person. Accessed April 10, 2015. http:// www.statcan.gc.ca/concepts/definitions/minority-minorite1-eng.htm Teixeira C (2006) Residential Segregation and Ethnic Economies in a Multicultural City: The Little Portugal of Toronto. In D Kaplan and W Li (Eds.), Landscapes of the Ethnic Economy. Lanham: Rowman and Littlefield, pp. 49-66.

Tuan YF (1977) Space and Place: The Perspective of Experience. Minneapolis : University of Minnesota Press. 
Vigdor JL (2013) Immigration and the Revival of American Cities: From Preserving Manufacturing Jobs to Strengthening the Housing Market. Partnership for a New Economy and Americas Society/Council on Americas white paper.

Waldinger R, Aldrich H, Ward R, and Associates (1990) Ethnic Entrepreneurs: Immigrant Business in Industrial Societies. Newbury Park, California: Sage.

Wang Q (2012) Ethnic Entrepreneurship Studies in Geography: A Review. Geography Compass 6(4): $227-240$.

Wang Q (2013) Constructing a Multilevel Spatial Approach in Ethnic Entrepreneurship Studies. International Journal of Entrepreneurial Behaviour and Research 19(1): 97-113.

Wang S (1996) New Development Patterns of Chinese Commercial Activity in the Toronto CMA. Toronto: Centre for the Study of Commercial Activity. Ryerson University.

Wang S (1999) Chinese Commercial Activity in the Toronto CMA: New Development Patterns and Impacts. Canadian Geographer 43(1): 19-35.

Whyte WH (1980) The Social Life of Small Urban Spaces. Washington, D.C.: Conservation Foundation.

Wood J (1997) Vietnamese American Place Making in Northern Virginia. Geographical Review 87(1): 58-72.

Yin, R K (2003) Case Study Research: Design and Methods (3rd ed.). Beverly Hills, CA: Sage. Zhou M, Logan JR (1989) Returns on Human Capital in Ethnic Enclaves: New York City's Chinatown. American Sociological Review 54(5): 809-920.

Zhou Y (1998) Beyond Ethnic Enclaves: Location Strategies of Chinese Producer Service Firms in Los Angeles. Economic Geography 74(3): 228-251. 


\section{Notes}

${ }_{1}$ Defined by the Employment Equity Act, visible minorities refer to "persons, other than Aboriginal peoples, who are non-Caucasian in race or non-white in colour" (Government of Canada 2015: 2). Statistics Canada adopts this definition and the Canadian Census currently includes the following self-reported visible minority groups: Chinese, South Asian, Black, Arab, West Asian, Filipino, Southeast Asian, Latin American, Japanese, and Korean (Statistics Canada 2015).

${ }^{2}$ A shopper intercept survey was used to obtain a quick overview of consumers' perspectives of the retail areas. Shoppers were randomly selected on the streets of each study area and asked about the purpose and experiences of their shopping trip. 
${ }^{3}$ Research has demonstrated that immigrants have more of a propensity for self-employment and entrepreneurship than their non-immigrant counterparts (Waldinger et. al, 1990). Four theories offer explanations of entrepreneurial behaviors and business strategies among different ethnic groups. First, the "cultural thesis" emphasizes ethnic resources (e.g., ethnic networks, group size and solidarity, family support, cultural values, etc.) and class resources (e.g., human capital, socioeconomic status, income and assets, education, business skills, etc.) that promote immigrant success in business (Bonacich and Modell 1980; Light and Gold 2000). Second, the notion of “opportunity structures" refers to both positive (e.g., protected markets and government policies) and negative (e.g., blocked social mobility and racial discrimination) factors that promote ethnic entrepreneurship (Light 1972; Waldinger et al. 1990). Third, the "interactive model” highlights the interaction between group characteristics and opportunity structures, resulting in the social embeddedness of ethnic strategies (Light and Rosenstein 1995; Waldinger et al. 1990). Fourth, a more recent concept, "mixed embeddedness," addresses the influences of laws, regulatory practices, and public institutions (Kloosterman and Rath 2001; Rath and Kloosterman 2000). 
${ }^{4}$ The participation of ethnic businesses in the general urban economy generates a series of subset economies, namely the ethnic economy, the ethnic enclave economy, and the mixed economy. An 'ethnic economy' consists of self-employed and co-ethnic employees (Light et al. 1994; Light and Gold 2000). An 'ethnic enclave economy' is a specific kind of ethnic economy: spatially clustered businesses with co-ethnic entrepreneurs, employees, and clientele (Portes and Manning 1986). The physical concentration of co-ethnic businesses in a territorially clustered place is considered a major component of the ethnic enclave economy. According to Light et al., "every immigrant group or ethnic minority has an ethnic economy, but only a few have an ethnic enclave economy” (1994: 73). A ‘mixed economy' reflects both ethnic and non-ethnic business components, and "their markets are spatially and ethnically unbounded" (Lo et al. 2000: 12). ${ }^{5}$ Italians were among the earliest immigrant groups to settle in Toronto and are still one of the largest ethnic groups in Canada, even though the Italian immigrant population has declined since the 1970s. The Chinese also have a long immigration history in Canada. In contrast to the Italians, the post-1967 immigration waves favored by the new immigration policy boosted the Chinese group as the second largest visible minority group according to the 2011 Canadian Census. South Asians have much shorter mass immigration history than the other two groups, but have grown very fast as the largest visible minority group.

${ }^{6}$ The Overseas Chinese Affairs Office of the State Council of P. R. China, and the government of the city of Jiangmen, China, donated archway building embossments and a pair of white stone lion sculptures, with a total worth of CAD $\$ 200,000$. 
7 Breton coined the term 'institutional completeness,' which refers to the number, size, and variety of institutions that an ethnic community has developed. These institutions may include formal "organizations of various sorts: religious, educational, political, recreational, national, and even professional ... Institutional completeness would be at its extreme whenever the ethnic community could perform all the services required by its members" (1964: 194). 